\title{
PENGELOLAAN KELAS DALAM PEMBELAJARAN BAHASA INDONESIA SISWA KELAS X SMA NEGERI 4 LEBONG
}

\author{
'Dessy Nur Aisyah; ${ }^{2}$ Didi Yulistio; ${ }^{3}$ Agus Joko Purwadi \\ 1,2,3 Program Studi Pendidikan Bahasa Indonesia Jurusan Pendidikan Bahasa dan \\ Seni FKIP Universitas Bengkulu
}

\section{Abstrak}

\section{Korespondensi: dessynuraisyah01@gmail.com}

Tujuan penelitian ini adalah untuk mendeskripsikan aspek pengelolaan kelas yang dilakukan oleh guru bahasa Indonesia di kelas X SMA Negeri 4 Lebong. Penelitian ini menggunakan metode penelitian deskriptif kualitatif. Sumber data dalam penelitian ini adalah guru yang mengajar bahasa Indonesia di kelas X IPS SMA Negeri 4 Lebong yang berjumlah satu orang. Data dalam penelitian ini adalah aspek kegiatan pengelolaan kelas yang meliputi pengaturan orang (siswa) dan pengaturan ruangan yang dilakukan oleh guru pada kegiatan pembelajaran bahasa Indonesia di kelas X IPS. Teknik pengumpulan data dalam penelitian ini observasi dan wawancara. Dalam penelitian ini, analisis data yang dilakukan yaitu merekam sambil mengamati guru mengajar pada saat proses belajar berlangsung, mewawancarai guru dengan pedoman wawancara yang dibuat penulis, mencatat proses jalannya proses pembelajaran di dalam kelas, mendeskripsikan data yang telah diperoleh dan menyimpulkan hasil pengamatan dan wawancara mengenai aspek mengelola kelas yang dilakukan oleh guru bahasa Indonesia. Hasil penelitian ini berbentuk deskripsi mengenai aspek pengelolaan kelas yang meliputi pengaturan siswa yang terdiri dari, guru menggunakan berbagai macam metode pembelajaran yang menarik minat siswa, guru memberikan motivasi belajar kepada siswa agar siswa semangat belajar, guru menghargai perbedaan pendapat siswa agar siswa tidak merasa dikucilkan, guru mampu menghidupkan suasana pembelajaran, sehingga terjalin komunikasi yang aktif antara guru dan siswa, guru menciptakan suasana kelas yang kondusif. Pengaturan ruangan atau fasilitas yang terdiri dari, penataan ruang kelas yang rapi dan nyaman, pengaturan dan pemanfaatan media yang menarik minat belajar siswa, pengaturan posisi tempat duduk siswa.

Kata Kunci: Pengelolaan, Aspek Pengaturan Siswa, Pengaturan Ruangan, Guru Bahasa Indonesia

\section{Abstract}

The purpose of this study was to describe the aspects of classroom management carried out by Indonesian language teachers in class X SMA Negeri 4 Lebong. This research uses descriptive qualitative research methods. Sources of data in this study are teachers who teach Indonesian in class X IPS 1 at SMA Negeri 4 Lebong, amounting to one person. The data in this study are aspects of classroom management activities which include the arrangement of people (students) and the arrangement of the room carried out by the teacher in Indonesian language learning activities in class X IPS. Data collection techniques in this study were observation and interviews. In this study, data analysis was carried out, namely recording while 
observing the teaching teacher during the learning process, interviewing the teacher with interview guidelines made by the author, recording the learning process in the classroom, describing the data that has been obtained and concluding the results of observations and interviews regarding aspects of class management carried out by Indonesian language teachers. The results of this study are in the form of descriptions of aspects of classroom management which include student management which consists of the teacher using a variety of learning methods that attract students' interest, the teacher provides learning motivation to students so that students are enthusiastic about learning, the teacher respects student differences of opinion so that students do not feel isolated, The teacher is able to liven up the learning atmosphere so that there is active communication between the teacher and students, the teacher creates a conducive classroom atmosphere. Arrangement of rooms or facilities consisting of, neat and comfortable classroom arrangement, arrangement and utilization of media that attract student learning interest, arrangement of student seating positions.

Keywords: management, students arrangement aspects, room arrangement, Indonesian language teacher

\section{PENDAHULUAN}

Sekolah merupakan salah satu pendidikan formal yang sangat membutuhkan tenaga ahli dalam bidang mengajar yakni guru. Guru merupakan sutradara sekaligus aktor yang bertanggung jawab atas keberlangsungan pembelajaran secara berkualitas. Peran guru dalam pengajaran meliputi banyak hal diantaranya, sebagai demonstator, fasilitator, motivator, pemacu belajar, perekayasa pembelajaran, pemberi inspirasi, dan evaluator. Selain hal-hal tersebut keberhasilan mengajar juga akan tergantung pada kemampuan guru dalam mengembangkan berbagai keterampilan mengajar. Keterampilanketerampilan ini sudah sepantasnya dikuasai oleh guru.

Keterampilan mengajar yang dimaksudkan itu paling tidak meliputi keterampilan menjelaskan, keterampilan bertanya, keterampilan menggunakan variasi, keterampilan memberi penguatan, keterampilan membuka dan menutup pelajaran, keterampilan mengajar kelompok kecil dan perorangan, dan keterampilan mengelola kelas.

Barnawi dan M. Arifin (2016:309) menyebutkan bahwa pengelolaan kelas merupakan suatu usaha yang dilakukan guru untuk membantu menciptakan kondisi belajar yang optimal atau suatu proses tindakan yang dilakukan guru dalam fungsinya sebagai penanggung jawab kelas dan seleksi penggunaan alat-alat belajar yang tepat sesuai dengan masalah dan karakteristik kelas yang dihadapi.

Penelitian pengelolaan kelas pernah dilakukan oleh Ghita Ulandari (2016), dalam penelitiannya yang berjudul "Pengelolaan kelas dalam Pembelajaran Bahasa Indonesia di Kelas VIII SMP Negeri 10 Kota Bengkulu Tahun Ajaran 2016/2017”. Penelitian ini menjelaskan tentang komponen pemeliharaan kondisi belajar (preventif) dan pengembalian kondisi belajar (represif). Data yang dijadikan dasar dalam penelitian ini adalah pengelolaan kelas pada mata pelajaran bahasa Indonesia di kelas VIII A dan di kelas VIII B. Hasil penelitian menunjukkan bahwa pemeliharaan kondisi belajar optimal (preventif) dalam pembelajaran bahasa Indonesia di kelas VIII A dan di kelas VIII B sudah dilaksanakan oleh guru. Pemeliharaan belajar yang optimal (preventif) terdiri dari beberapa aspek sebagai berikut : menunjukkan sikap tanggap, membagi perhatian, memusatkan perhatian kelompok, memberi petunjuk-petunjuk yang jelas dan memberi 


\section{Dessy Nur Aisyah; Didi Yulistio; Agus Joko Purwadi}

penguatan. Pengembalian kondisi belajar (represif) dalam pembelajaran bahasa Indonesia di kelas VIII A dan di kelas VIII B sudah dilaksanakan oleh guru. Pengembalian kondisi belajar (represif) ada 3 aspek yaitu: modivikasi tingkah laku, pengelolaan kelompok, menemukan dan memecahkan tingkah laku yang menimbulkan masalah.

Penelitian selanjutnya dilakukan oleh Sri Warsono tahun (2016), dalam penelitiannya yang berjudul "Pengelolaan Kelas dalam Meningkatkan Belajar Siswa". Penelitian ini mendeskripsikan tentang perencanaan pengelolaan kelas, pelaksanaan pengelolaan kelas, pengawasan pengelolaan kelas dan faktor pendukung dan faktor penghambat pengelolaan kelas dalam meningkatkan belajar siswa. Hasil penelitian menunjukkan bahwa perencanaan pengelolaan kelas dilakukan dengan menerapkan beberapa prinsip pengelolaan kelas dan bebrapa pendekatan, pengawasan dilakukan secara terus menerus, faktor pendukung dan faktor pengambat pengelolaan kelas adalah lingkungan fisik, sosial, kondisi emosional dan organisasi.

Berdasarkan situasi dan kondisi covid-19 yang terjadi saat ini, pembelajaran yang efektif sukar didapat karena keterbatasan waktu guru dalam menjelaskan materi pelajaran. SMA Negeri 4 Lebong yang terletak di desa Suka Negeri Kecamatan Topos Kabupaten Lebong merupakan salah satu sekolah yang masih melaksanakan kegiatan belajar mengajar karena merupakan kawasan yang masih berzona hijau. Waktu untuk guru mengajar di dalam kelas adalah selama 20 menit. Dalam waktu yang sangat terbatas ini guru dituntut untuk mampu mengajar dari mulai membuka pembelajaran, menjelaskan, bertanya, menggunakan variasi media, memberi penguatan kepada siswa, memberi tugas dan menutup pelajaran. Guru dan siswa juga harus mengikuti protokol kesehatan yaitu memakai masker, dan sering mencuci tangan di sekolah. Dalam hal ini, guru harus memperhatikan pengelolaan kelas dengan pengajaran yang dilakukan. Siswa harus dibuat supaya terus-menerus memberikan reaksi pada lingkungan, sehingga pengalaman belajar dapat terjadi sesuai dengan kondisi yang diinginkan walaupun sedang berada dimasa pandemi covid-19.

Dari pemaparan sebelumnya maka sebagai calon guru atau guru dituntut untuk bisa mengelola kelas dengan baik karena pengelolaan kelas merupakan hal yang sangat penting. Dengan adanya pengelolaan kelas guru dapat mengondisikan situasi dalam kelas, sehingga siswa dapat mengikuti proses belajar mengajar akan tertib, guru dan siswa melaksanakan hak dan kewajiban sebagai warga sekolah, sehingga pembelajaran seharihari dapat kondusif dan berjalan dengan lancar, maka dalam hal ini penulis memilih judul Pengelolaan Kelas dalam Pembelajaran Bahasa Indonesia Siswa Kelas X SMA Negeri 4 Lebong yang khususnya akan membahas mengenai aspek pengelolaan kelas di yang akan mendeskripsikan bagaimana guru mengajar agar pembelajaran lebih efektif dan tujuan pembelajaran dapat tercapai.

\section{METODE}

Penelitian ini menggunakan pendekatan kuantitatif dengan metode deskriptif kualitatif yaitu penelitian ini dilakukan eksplorasi, menggambarkan, dengan tujuan untuk dapat menerangkan dan memprediksi terhadap suatu gejala yang berlaku atas dasar data yang diperoleh di lapangan yang diarahkan untuk memecahkan masalah dengan tujuan memaparkan atau menggambarkan apa adanya hasil penelitian. Penelitian ini dilakukan di SMA Negeri 4 Lebong. Waktu penelitian ini dilakukan pada semester ganjil tahun ajaran 2019/2020. 
Sumber data dalam penelitian ini adalah guru yang mengajar bahasa Indonesia di kelas X IPS 1 di SMA Negeri 4 Lebong yang berjumlah satu orang. Adapun teknik penumpulan data dalam penelitian ini adala observasi dan wawancara. Dalam penelitian kualitatif, yang menjadi instrumen atau alat penelitian adalah peneliti itu sendiri, namun setelah fokus penelitian menjadi jelas dan untuk melengkapi data, maka penulis menggunakan alat pedoman observasi dan pedoman wawancara sesuai dengan teknik pengumpulan data yang digunakan dan selama proses pembelajaran berlangsung direkam oleh bandphone merk MI not 5A.

Setelah data penelitian terkumpul maka, untuk mengetahui gambaran tersebut maka hal yang dilakukan adalah, merekam sambil mengamati guru mengajar pada saat proses belajar berlangsung, mewawancarai guru dengan pedoman wawancara yang dibuat penulis, mencatat proses jalannya proses pembelajaran di dalam kelas, mendeskripsikan data yang telah diperoleh dan proses yang terakhir adalah menyimpulkan hasil pengamatan dan wawancara mengenai aspek mengelola kelas yang dilakukan oleh guru bahasa Indonesia.

\section{HASIL DAN PEMBAHASAN}

\section{Hasil}

Hasil penelitian berbentuk deskripsi mengenai aspek pengelolaan kelas yang meliputi pengaturan siswa dan pengaturan ruangan dalam pembelajaran bahasa Indonesia di kelas X SMA Negeri 4 Lebong. Berdasarkan penelitian yang dilakukan selama tiga kali pengamatan pada kegiatan pembelajaran, ditemukan beberapa kegiatan guru mengatur siswa yaitu pengaturan (orang) siswa dan pengaturan ruangan. Seperti yang kita ketahui bahwa siswa adalah orang yang melakukan aktivitas dan kegiatan di dalam kelas yang ditempatkan sebagai objek. Pengaturan siswa meliputi : guru menggunakan berbagai metode dalam mengajar, guru harus memberikan motivasi belajar kepada siswa, guru menghargai perbedaan pendapat siswa agar siswa tidak merasa dikucilkan, guru mampu menghidupkan suasana pembelajaran, sehingga terjalin komunikasi yang aktif antara guru dan siswa, guru harus menciptakan suasana kelas yang kondusif.

Selanjutnya, pengaturan fasilitas. Pengaturan fasilitas banyak dipengaruhi oleh kondisi dan situasi fisik lingkungan kelas. Oleh karena itu, lingkungan fisik kelas berupa sarana dan prasarana kelas dapat memenuhi dan mendukung interaksi yang terjadi, sehingga harmonisasi kehidupan kelas dapat berlangsung dengan baik dan nyaman. Pengaturan fasilitas meliputi : penataan ruang kelas yang rapi dan nyaman, pengaturan dan pemanfaatan media dan pengaturan posisi tempat duduk siswa.

\section{Pembahasan}

Penelitian tentang Pengelolaan Kelas dalam Pembelajaran Bahasa Indonesia sudah beberapa kali dilakukan, Seperti Pengelolaan kelas dalam Pembelajaran bahasa Indonesia di kelas VIII SMP Negeri 10 Kota Bengkulu Tahun Ajaran 2016/2017. Hasil temuan dalam penelitian ini menyebutkan bahwa pemeliharaan dan pengembalian kondisi belajar yang optimal sudah dilakukan oleh guru bahasa Indonesia pada kelas VIII A dan kelas VIII B. Penelitian ini memang lebih fokus membahas tentang bagaimana guru mengelola kelas berdasarkan komponen pengelolaan kelas yang berkaitan dengan pemeliharaan kondisi kelas dan pengembalian kondisi kelas menjadi kondusif apabila terjadi gangguan. 


\section{Dessy Nur Aisyah; Didi Yulistio; Agus Joko Purwadi}

Dari hasil pengamatan penulis, penulis ingin mendeskripsikan bagaimana pengelolaan kelas yang dilakukan oleh guru bahasa Indonesia di SMA Negeri 4 Lebong dengan memfokuskan pada aspek pengelolaan kelasnya yang meliputi pengaturan siswa dan pengaturan ruangan. Sejalan dengan teori dari Rohani (2004:128), terdapat dua aspek dalam pengelolaan kelas, yaitu pengaturan (orang) siswa. Siswa adalah orang yang melakukan aktivitas dan kegiatan di dalam kelas yang ditempatkan sebagai objek dan arena perkembangan ilmu pengetahuan dan kesadaran manusia maka, siswa bergerak kemudian menduduki fungsi sebagai objek. Untuk membuat seorang siswa kreatif dan tidak jenuh dalam belajar, maka guru di tuntut untuk memberikan bermacaam-macam metode dalam menajar.

Metode merupakan cara atau strategi pendidik untuk dapat berinteraksi dengan peserta didik agar tujuan pembelajaran dapat tercapai. Metode pembelajaran membantu proses belajar mengajar agar siswa dapat lebih mengerti mengenai materi yang sedang diajarkan. Setelah dilakukan observasi selama 3 kali pertemuan, dapat disimpulkan bahwa guru lebih cenderung menggunakan metode diskusi belajar kelompok pada saat pembelajaran. Metode diskusi kelompok dapat meningkatkan kreativitas siswa, karena siswa dapat berinteraksi dan bekerja sama dengan teman yang lain untuk memecahkan suatu masalah atau mengerjakan latihan yang diberikan oleh guru. Belajar kelompok merupakan salah satu metode belajar yang kerap digunakan di dalam kegiatan belajar mengajar di sekolah. Belajar kelompok sangat baik untuk dilakukan karena bisa melatih interaksi sosial antara siswa dengan siswa dan dapat menyelesaikan masalah bersamasama karena siswa bisa saling membantu satu sama lain. Menurut Abu Ahmadi, 2004:111) belajar kelompok adalah suatu kegiatan yang dilakukan oleh dua orang atau lebih untuk membahas suatu materi pelajaran yang sedang dihadapinya.

Dalam pelaksanaan pembelajaran, peserta didik dibagi menjadi tiga kelompok, kelompok tersebut guru pilih dengan tidak mempertimbangkan pengelompokan menurut kesenangan siswa berteman, pengelompokan kemampuan siswa dan pengelompokan menurut minat siswa. Kelompok tersebut guru pilih secara langsung dengan memperhatikan tempat duduk siswa dalam barisan kursi, maksudnya guru membagi kelompok perbaris tempat duduk. Baris yang paling kanan sampai ke belakang adalah kelompok satu baris kedua kursi yang di tengah-tengah adalah kelompok dua dan baris kursi sebalah kiri adalah kelompok tiga. Namun dengan demikian akan terbentuklah kelompok-kelompok yang heterogen. Anggota kelompok yang heterogen berbeda dalam banyak hal, sedangkan anggota kelompok yang homogen mempunyai kesamaan dalam satu al pokok, misalnya taraf kemampuan belajar. Pembentukan kelompok yang heterogen atau yang homogen tergantung pada kesesuaian tujuan pembelajaran serta sifat isi materi pelajaran.

Selain menggunakan metode belajar yang bervariasai, guru juga harus memberikan motivasi belajar kepada siswa. Menurut Sardiman (2007: 75), motivasi belajar adalah faktor psikis yang bersifat non intelektual. Peranan yang khas adalah hal yang menumbuhkan gairah, merasa senang dan semangat untuk belajar. Dalam hal ini, motivasi menjadi hal yang sangat penting dalam belangsungnya kegiatan belajar mengajar di dalam kelas. Bersadarkan observasi dan wawancara yang telah dilakukan penulis bahwa guru di SMA Negeri 4 Lebong memberikan motivasi belajar kepada siswa dengan berbagai cara diantaranya dengan menjelaskan tujuan pembelajaran, memberikan apresiasi dan kebiasaan-kebiasaan belajar yang baik yaitu dengan berkelompok. Dua 
pembangkit motivasi belajar yang efektif adalah keingintahuan dan keyakinan akan kemampuan diri. Setiap siswa memiliki rasa ingin tahu. Guru perlu menyalurkan dengan cara, mengajukan pertanyaan. Keyakinan akan kemampuan itu dapat tumbuh dengan memberikan tugas yang dapat diselesaikan siswa. Guru perlu memberikan penguaran bahwa siswa pasti bisa. Hal-hal yang dilakukan guru tersebut akan memberikan motivasi kepada siswa khususnya kelas X yang baru menjajaki sekolah di tingkat sekolah menengah atas. Siswa kelas X masih sengat perlu perhatian secara khusus oleh guru. Di SMA Negeri 4 Lebong, guru sangat menghargai perbedaan pendapat siswa agar siswa tidak merasa dikucilkan. Hal utama yang paling penting untuk bisa dilakukan yaitu dengan saling menghargai. Dengan saling menghargai, maka akan memberikan manfaat yang baik, serta tidak terjadi permasalahan yang memang tidak diinginkan. Tidak akan ada manfaat dari masalah yang terjadi. Sebaliknya, jika saling menghargai satu sama lain maka akan bermanfaat apalagi hubungan antara siswa dan guru.

Berdasarkan observasi yang telah dilakukan oleh penulis, terlihat guru sangat menghargai pendapat-pendapat dari peserta didik. Pendapat siswa yang beragam itu Ia tampung dan kemudian disimpulkan dengan bahasa sendiri. Dalam hal ini, tidak jarang seorang pendidik yang mengecam tidak baik apabila peserta didik menjawab kurang tepat. Akibatnya peserta didik menjadi takut berpendapat. Seorang guru juga tidak boleh membeda-bedakan antara siswa yang pintar ataupun kurang pintar. Tugas guru adalah mendidik semua peserta didik dari yang tidak bisa menjadi bisa, dari yang tidak paham menjadi paham, dan dari yang belum baik menjadi lebih baik. Bagusnya, guru memberikan perhatian lebih untuk siswa yang kurang pandai dalam memahami materi di kelas, seperti bimbingan belajar agar siswa dapat mengerjar ketertinggalan itu. Karena sebagai guru pasti sangat tau kemampuan masing-masing peserta didik. Guru memegang peranan penting dalam jalannya proses pembelajaran. Guru perlu menciptakan suasana yang menyenangkan di dalam kelas agar siswa juga senang selama proses pembelajaran berlangsung. Keaktifan siswa dalam belajar sangat menentukan pencapaian tujuan pembelajaran.

Menurut Abu Ahmadi, (2004:13) proses belajar adalah proses yang melibatkan berbagai aktivitas para siswa, untuk itu guru seharusnya mengaktifkan kegiatan belajar mengajar. Berdasarkan observasi yang dilakukan di kelas X SMA Negeri 4 Lebong, guru bahasa Indonesia mampu menumbuhkan minat belajar siswa diawali dengan pemberian ice breaking. Guru memulai pembelajaran dengan mengecek kehadiran, kemudian guru mengarahkan peserta didik untuk membuang sampah, yang ada di tempat duduk masingmasing siswa. Tujuannya agar kelas tetap dalam keadaan bersihdan rapi. Kemudian sebelum memulai pembelajaran, guru menyuruh siswa untuk berdiri dan menyanyikan lagu agar siswa kembali bersemangat dalam belajar. Selama proses pembelajaran berlangsung, guru sangat bersemangat dalam mengajar, siswa pun terpancing bersemangat juga dalam belajar. Guru juga harus mampu arus menciptakan suasana kelas yang kondusif. Menurut menurut Asril (2010:73-75) pada umumnya penciptaan kelas yang kondusif, guru harus melakukan tindakan preventif yaitu yang berhubungan dengan tindakan penciptaan dan pemeliharaan kondisi optimal, sedangkan represif berhubungan dengan tindakan untuk mengembalikan kondisi belajar menjadi optimal. Keterampilan pengelolaan preventif berkaitan dengan kemampuan guru dalam mengambil inisiatif dan mengendalikan pelajaran. Saat kegiatan belajar di dalam kelas berlangsung, suasana di dalam kelas pasti akan berubah-ubah di setiap waktu. Dalam mengajar, guru akan 


\section{Dessy Nur Aisyah; Didi Yulistio; Agus Joko Purwadi}

menerima berbagai macam gangguan, yang banyak terjadi adalah gangguan itu muncul dari siswa itu sendiri. Misalnya ada siswa yang ribut, atau mengobrol dengan teman lain bisa juga keluar masuk kelas yang bisa menghilangkan fokus guru dalam mengajar dan menghilangkan fokus siswa lain sat menyerap pelajaran yang sedang guru sampaikan.

Di SMA Negeri 4 Lebong, bahwa guru telah berusaha menciptakan suasana kelas yang kondusif. Guru bertanggung jawab dengan tuganya untuk selalu menjaga ketertiban kelas agar selalu kondusif. Strategi yang dilakukan guru pada saat kelas mengalami gangguan dari siswa yang ribut adalah menegur dan menasehati siswa. Tujuannya agar siswa kembali fokus ke pelajaran dan lebih menghargai guru saat guru sedang menjelaskan di depan kelas. Suasana kelas yang kondusif berpengaruh terhadap tingkah laku siswa saat proses pembelajaran berlangsung. Jika saat ada siswa yang ribut di dalam kelas, namun guru membiarkannya dalam kata lain tidak menegurnya tentu saja suasana kelas akan menjadi tidak kondusif dan semakin gaduh. Guru memiliki andil yang besar dalam rangka membimbing, mengarahkan, dan memandu segala aktivitas yang dilakukan oleh siswa. Siswa kelas X merupakan siswa yang masih mengalami transisi dari pendidikan menengah pertama ke pendidikan menengah atas maka dari itu siswa masih sangat butuh arahan, bimbingan, aturan dan teguran dari guru karena mereka akan dituntut untuk lebih mandiri dalam belajar. Aktivitas dalam kelas, baik guru maupun siswa keberlangsungannya akan banyak dipengaruhi oleh kondisi dan situasi fisik lingkungan kelas. Pengaturan fasilitas meliputi pengaturan tempat duduk, pengaturan alat pengajaran penataan keindahan dan kebersihan ruang kelas.

Penataan ruangan kelas diperlukan perhatian dan perencanaan yang sungguhsungguh dalam proses pembelajaran. Penataan ruang kelas penting dilakukan dengan terencana dan mendukung proses pembelajaran. Berdasarkan observasi yang dilakukan oleh penulis didapatkan hasil bahwa ruang kelas X IPS terlihat kurang rapi. Guru hanya mengarakan siswa untuk selalu menjaga keindahan dan kebersihan kelas tetapi tidak terlihat berperan menata ruang fisik kelas. Terlihat dari banyaknya kursi meja yang bertumpuk di belakang kelas. Seharusnya kursi dan meja yang tidak dipergunakan diletakkan di gudang atau ruangan lain karna jika diletakkan di dalam kelas akan mengurangi rasa nyaman siswa dan guru dalam belajar dan mengajar. Pengaturan ruangan kelas merupakan salah satu bentuk dari kemampuan guru dalam mengelola kelas untuk menciptakan suasana kelas yang kondusif. Ruang kelas bukanlah tempat yang luas bagi puluhan orang saling berinteraksi dalam waktu yang lama sekitar 5-8 jam sehari. Guru dan siswa akan senantiasa terlibat dalam berbagai kegiatan kegiatan pembelajaran di dalam ruangan kelas tersebut.

Setelah kelas disusun secara rapi, maka yang guru lakukan selanjutnya adalah menyiapkan media pembelajaran. Media pembelajaran dimanfaatkan untuk menunjang tercapainya tujuan tertentu. Pemanfaatannya pun dipadukan dengan proses belajar mengajar dalam situasi kelas. Di SMA Negeri 4 Lebong fasilitas penunjang pembelajaran masih kurang. Di sekolah lain yang lebih maju guru mengajar tidak hanya berfokus pada buku paket saja namun sudah memakai power point untuk menunjang belajar siswa. Pembelajaran bisa dilakukan dengan menayangkan gambar atau video melalui infokus tujuannya agar siswa bergairah untuk belajar. Namun di SMA Negeri 4 Lebong guru tidak bisa menayangkan PPT maupun vidio karna kurangnya fasilitas berupa kabel dan tidak adanya colokan listrik disetiap kelas. Guru menggunakan media berupa media cetak yaitu buku LKS dan buku paket. Sebenarnya media elektronik dapat digunakan guru untuk 
membuat siswa lebih bergairah dalam belajar karena melalui media elektronik guru dapat menampilkan pembelajaran dalam bentuk video, gambar ataupun PPT. Media elektronik juga digunakan untuk mempermudah seseorang dalam melakukan sesuatu. Namun karena kurangnya sarana dan prasarana di sekolah guru hanya memanfaatkan media yang ada. Meskipun demikian, guru juga harus maksimal memberikan ilmu kepada siswa sesuai rencana pembelajaran yang dibuat. Karena seyogyanya pembelajaran yang berkualitas tidak hanya di ukur dari kelengkapan fasilitas siswanya tetapi dari bagaimana guru mampu menyampaikan pembelajaran kepada siswa dan siswa bisa memahami apa yang guru sampaikan. Setelah ruangan di tata dengan rapi, dan media pembelajaran telah dipersiapkan dengan baik, maka yang guru lanjutkan selanjutnya adalah mengatur posisi tempat duduk siswa. Tempat duduk mempengaruhi anak didik dalam belajar. Bila tempat duduk bagus, tidak terlalu rendah, tidak terlalu besar, tidak berat, bundar, persegi empat panjang, dan sesuai dengan postur tubuh anak didik dapat belajar dengan baik dan tenang.

Tujuan utama penataan lingkungan fisik kelas yaitu pengaturan posisi tempat duduk siswa adalah mengarahkan kegiatan siswa dan mencegah tindakan yang tidak di inginkan muncul di dalam kelas. Penataan tempat duduk adalah salah satu upaya yang dilakukan guru dalam mengelola kelas. Dengan penataan kelas yang baik, diharapkan mampu menciptakan fisik kelas yang kondusif. Winzer (dalam Winataputra, 2003: 9-21) menyatakan bahwa penataan lingkungan kelas yang tepat berpengaruh terhadap tingkat keterlibatan dan partisipasi siswa dalam proses pembelajaran.

Setelah dilakukan observasi, bahwa pengaturan tempat duduk siswa diatur secara berderet. Dalam kelas, diisi oleh 13 orang siswa karena kondisi covid. Sebenarnya jumlah siswa dalam satu kelas adalah 26 siswa. Siswa juga diarahkan untuk duduk berkelompok saat guru mengarahkan untuk duduk secara berkelompok, namun tetap di ingatkan untuk menjaga jarak dan memakai masker.

\section{PENUTUP}

Berdasarkan hasil penelitian dan pembahasan dalam mendeskripsikan aspek pengelolaan kelas dalam pembelajaran bahasa Indonesia siswa kelas X SMA Negeri 4 Lebong maka dapat disimpulkan bahwa semua unsur dalam aspek pengaturan siswa belum semuanya terpenuhi atau belum dilaksanakan oleh guru yaitu menggunakan berbagai macam metode dalam mengajar. Pada pelaksanaan kegiatan pembelajaran di dalam kelas, guru cenderung menggunakan metode belajar kelompok, padahal guru bisa menggunakan berbagai macam metode dalam mengajar yang bisa menambah keinginan/minat siswa dalam belajar di dalam kelas. Penggunaan metode belajar yang berbeda-beda akan membuat siswa semangat belajar dan tidak bosan belajar karena guru mengajar dengan cara yang berbeda dan tidak monoton. Metode belajar kelompok memang baik dilaksanakan, namun jika pada setiap pertemuan metode itu-itu saja yang dipakai oleh guru, maka siswa akan jenuh dengan proses pembelajaran tersebut.

Dalam aspek pengaturan ruangan/fasilitas, semua unsur dalam aspek pengaturan ruangan/fasilitas semuanya sudah terpenuhi dan dilaksanakan oleh guru.

\section{DAFTAR RUJUKAN}

Abu,Ahmadi.(2004). Psikologi Belajar. Jakarta : Rineka Cipta.

Arifin dan Barnawi. (2016). Teori dan Praktik Pengajaran yang Efektif \& Kreatif. Yogyakara:AR-RUZZ MEDIA. 
Dessy Nur Aisyah; Didi Yulistio; Agus Joko Purwadi

Asril, Zainal. 2011. Micro Teacing : Disertai dengan program pengalaman Lapangan, Jakarta: Rajawali

Rohani, A. 2004. Pengelolaan Pengajaran. Jakarta: PT. Rineka Cipta.

Warsono, Sri. 2016. Pengelolaan Kelas dalam Meningkatkean Belajar. e-Journal Unib, Volume 10, Nomor 5, November 2016.

Sardiman. 2007. Interaksi \& Motivasi Belajar Mengajar. Jakarta : PT Rineka Cipta.

Udin S Winataputra,(2003) . Strategi Belajar Mengajar. Skripsi. Universitas Terbuka Departemen Pendidikan Nasional. Diakses: Rabu, 14 Oktober pukul 19.00. 